\title{
O gênero Inga (Leguminosae-Mimosoideae) na Província Petrolífera de Urucu, Coari, Amazonas, Brasil
}

\section{The genus Inga (Leguminosae-Mimosoideae) in the Urucu Petroleum Province, Coari, Amazonas, Brazil}

\author{
Julio dos Santos de Sousa ${ }^{1,2}$, Maria de Nazaré do Carmo Bastos ${ }^{2}$ \\ \& Ely Simone Cajueiro Gurgel ${ }^{2}$
}

\begin{abstract}
Resumo
Este trabalho trata do estudo taxonômico de Inga Mill. da Província Petrolífera de Urucu, Coari-AM. O gênero está representado na área por nove táxons, distribuídos em cinco seções: Pseudinga Benth., composta por Inga nobilis Willd. subsp. nobilis e Inga stenoptera Benth.; Bourgonia Benth., por Inga laurina (Sw.) Willd., Inga alba (Sw.) Willd. e Inga pezizifera Benth.; Longiflorae (Benth.) T.D. Penn., por Inga rubiginosa (Rich.) DC. e Inga calantha Ducke; Inga e Leptinga Benth., respectivamente, por Inga edulis Mart. e Inga heterophylla Willd. São apresentadas chave de identificação, descrições e ilustrações dos táxons, bem como dados adicionais sobre distribuição geográfica, comentários e hábitat dos mesmos.
\end{abstract}

Palavras-chave: Inga, Amazônia, florística, morfologia, taxonomia.

\begin{abstract}
This study deals with the taxonomic treatment of Inga Mill. from Urucu Petroleum Province, Coari-AM. The genus is represented by nine taxa, distributed in five sections: Pseudinga Benth., composed by Inga nobilis Willd. subsp. nobilis and Inga stenoptera Benth.; Bourgonia Benth., by Inga laurina (Sw.) Willd., Inga alba (Sw.) Willd. and Inga pezizifera Benth.; Longiflorae (Benth.) T.D. Penn., by Inga rubiginosa (Rich.) DC. and Inga calantha Ducke; Inga and Leptinga Benth., respectively, by Inga edulis Mart. and Inga heterophylla Willd. Are given identification key, descriptions, and illustrations of the taxa, as well as data concerning geographical distribution, additional comments and habitat of the taxa.
\end{abstract}

Key words: Inga, Amazonia, floristics, morphology, taxonomy.

\section{Introdução}

Inga Mill. pertence aLeguminosae-Mimosoideae, tribo Ingeae e compreende cerca de 300 espécies (Sousa 2009). Destas, 140 são referidas para o Brasil, com 93 na região fitogeográfica do litoral brasileiro (Mata \& Félix 2007). O nome do gênero é derivado do Tupi-Guarani, vernacularmente conhecido como ingá (Lewis et al. 2005).

Trata-se de um gênero exclusivamente neotropical, com sete principais áreas de distribuição, das quais o litoral, o interior do Brasil, o sudeste da América Central e o oeste da América do Sul, constituem os principais centros de diversidade do gênero (Pennington 1997; Mata \& Felix 2007).

Inga caracteriza-se basicamente por apresentar folhas paripenadas, com nectário na raque foliar, localizado entre cada par de folíolo e legume, com sementes envolvidas por sarcotesta carnosa e adocicada (Bentham 1876). Apresenta potencial econômico no reflorestamento, fitoterapia, produção de energia e alimentação (Pritchard et al. 1995; Bilia 2003; Caramori et al. 2008).

De acordo com Richardson et al. (2001), sinapomorfias moleculares e a presença da sarcotesta (característica esta única em Mimosoideae) sustentam Inga como monofilético.

Apesar de ser um grupo bastante representado na região amazônica, ainda são poucos os trabalhos com ênfase no Amazonas, principalmente em uma área de clareiras naturais e antrópica como a Base Petrolífera de Urucu, o que levou a realização deste estudo, o qual objetivou tratar taxonomicamente as espécies de Inga Mill. e contribuir para o conhecimento da flora no estado.

\footnotetext{
'Autor para correspondência: jssousa27@yahoo.com.br

${ }^{2}$ Museu Paraense Emílio Goeldi, MCT, Campus de Pesquisa, Coord. Botânica, Av. Perimetral 1901, Terra Firme, 66017-970, Belém, PA.
} 


\section{Material e Métodos}

A área de estudo localiza-se na Base Operacional Geólogo Pedro de Moura (BOGPM), comumente chamada de Base Petrolífera de Urucu

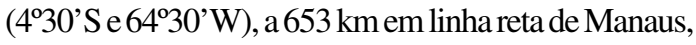
na bacia do Rio Urucu, afluente da margem direita do Rio Solimões, caracterizada por uma vegetação de floresta alta e densa de terra firme, no município de Coari, no estado do Amazonas (Lima et al. 2008).

O material botânico foi coletado nas clareiras da Base Petrolífera de Urucu nos anos de 2005-2009 e incorporado nos herbários do Museu Paraense Emílio Goeldi (MG) e da Empresa Brasileira de Pesquisa Agropecuária/Embrapa Amazônia Oriental, Belém, Pará, Brasil (IAN). Para a coleta, preservação e herborização dos espécimes foram adotadas as recomendações técnicas propostas por Fidalgo \& Bononi (1984). A terminologia utilizada para as estruturas morfológicas está baseada nos trabalhos de León (1966), Sousa (1993), Pennington (1997), Garcia (1998) e Sousa (2009). A identificação dos táxons foi realizada por comparação com o material herborizado e certificado por especialistas, análise dos tipos, quando disponíveis, chaves analíticas, diagnoses e descrições existentes na literatura. As ilustrações foram feitas com o auxílio de um estereomicroscópio ZEISS, acoplado à câmara clara, em diversas escalas de aumento, utilizando-se a técnica de nanquim, sobre papel vegetal, à mão livre.

Neste trabalho, são acatadas as considerações de Lewis et al. (2005), que mantêm Leguminosae como uma única família, dividida em três subfamílias.

\section{Resultados e Discussão}

Inga Mill.

Árvores até $25 \mathrm{~m}$ de alt. Ramos cilíndricos, semicilíndricos ou angulosos. Estípulas presentes.
Pecíolo e raque alados ou não. Nectário foliar entre cada par de folíolos, sésseis ou estipitados. Folhas compostas, alternas, paripinadas e com 1-6 jugas. Inflorescências axilares, racemosas, espiciformes ou umbeliformes. Brácteas persistentes ou caducas. Flores pentâmeras, actinomorfas, andróginas, gamossépalas, gamopétalas; estames 28-100, monadelfos; anteras bitecas; ovário unicarpelar, com 16-30 óvulos. Legume típico ou nucóide ou folículo, reto, curvado ou torcido, coriáceos a lenhosos, glabros, híspidos, puberulentos ou velutinos. Sementes elipsóides, oblongas ou obovadas, lisas a rugosas, envolvidas por sarcotesta carnosa e adocicada.

Inga é o gênero mais representativo da tribo Ingeae, com ca. 300 espécies, distribuídas em 14 secções (Pennington 1997). Destas, 140 espécies foram registradas para o Brasil (Mata \& Felix 2007), cuja ocorrência é notada em todos os estados, sendo 75 essencialmente Amazônicas (Lewis 2005), com a bacia amazônica contituindo seu maior centro de diversidade (Ducke 1949). Possui distribuição exclusivamente neotropical, de um extremo ao outro da zona tropical úmida, desde $24^{\circ} \mathrm{N}$, no México, até $34^{\circ} \mathrm{S}$, no Uruguai, com representantes nas Antilhas Maiores e Menores (Pennington 1997).

Na Base Operacional Geólogo Pedro de Moura, Inga está representado por oito espécies e uma subespécie, distribuídas em cinco seções: Pseudinga Benth., composta por I. nobilis Willd. subsp. nobilis e I. stenoptera Benth.; Bourgonia Benth., por I. laurina (Sw.) Willd., I. alba (Sw.) Willd. e I. pezizifera Benth.; Longiflorae (Benth.) T.D. Penn., por I. rubiginosa (Rich.) DC. e I. calantha Ducke; Inga e Leptinga Benth., respectivamente, por I. edulis Mart. e I. heterophylla Willd.

\section{Chave para identificação dos táxons}

1. Raque alada.

2. Ramos velutinos; estípulas ovais, velutinas; folíolos velutinos; tubo estaminal 4,7-6 cm compr.; fruto densamente híspido 2. I. calantha

2'. Ramos glabros a tomentosos; estípulas lanceoladas ou oblongas, glabras a pubescentes; folíolos glabros ou puberulentos; tubo estaminal 0,4-2 cm compr.; fruto glabro ou esparsamente tomentoso.

3. Pecíolos alados somente no ápice; nectários foliares estipitados até $1 \mathrm{~mm}$ compr.; folíolos com ápice acuminado; inflorescências umbeliformes; flores pediceladas; legume nucóide

4. I. heterophylla

3'. Pecíolos não alados ou alados em toda a extensão; nectários foliares sésseis; folíolos com ápice agudo, obtuso, cuspidado ou atenuado; inflorescências espiciformes; flores sésseis; legume ou folículo. 
4. Brácteas ovais; fruto estipitado.

5. Nectários foliares reniformes; folhas 4-6 jugas; folíolos discolores, puberulentos, base arredondada, truncada ou assimétrica; cálice tubular; corola com lobos seríceo-vilosos; ovário oblongo; estigma cupuliforme; folículo 30-180 cm compr., com nervações longitudinais, profundamente sulcado, esparsamente tomentoso, margens lobadas 3. I. edulis

5'. Nectários foliares cupuliformes; folhas 2-3 jugas; folíolos concolores, glabros, base aguda; cálice cupuliforme; corola com lobos puberulentos; ovário elipsóide; estigma globoso; legume 3,7-15,2 cm compr., com nervações transversais, não sulcado, glabro, margens onduladas ....

5. I. laurina

4'. Brácteas espatuladas ou elípticas; fruto não estipitado.

6. Estípulas lanceoladas, esparsamente pubescentes, persistentes; nectários foliares cupuliformes; folhas 2-3 jugas; folíolos concolores, nervuras secundárias 9-12 pares; brácteas elípticas, persistentes; cálice tubular; corola com lobos seríceos a vilosos; estigma cupular; fruto não apiculado

9. I. stenoptera

6'. Estípulas oblongas, puberulentas, caducas; nectários foliares pateliformes ou ciatiformes; folhas 3-6 jugas, folíolos discolores, nervuras secundárias 5-9 pares; brácteas espatuladas, caducas; cálice cupuliforme; corola com lobos puberulentos; estigma globoso; fruto apiculado

1. I. alba

1'. Raque não alada.

7. Ramos puberulentos; estípulas oblongas a lanceoladas; nectários foliares cupuliformes; inflorescências racemosas; flores pediceladas; cálice 1-2,5 mm compr.; tubo estaminal igualando a corola; estigma globoso; fruto não apiculado

7. I. pezizifera

7'. Ramos tomentosos ou velutinos; estípulas elípticas ou ovais; nectários foliares pateliformes; inflorescências espiciformes; flores sésseis; cálice 3-7 mm compr.; tubo estaminal incluso ou exserto; estigma expandido; fruto apiculado.

8. Ramos tomentosos; estípulas elípticas, pubescentes, persistentes; folíolos coriáceos, concolores, glabros a esparsamente pubescentes; brácteas espatuladas, tomentosas, persistentes; cálice e corola infundibuliformes; estames 38-60; óvulos 12-16; legume nucóide, puberulento, ápice obtuso ou arredondado; sementes oblongóides 6. I. nobilis subsp. nobilis

8'. Ramos velutinos; estípulas ovais, velutinas, caducas; folíolos cartáceos, discolores, velutinos; brácteas ovais, velutinas, caducas; cálice cupuliforme e corola tubular; estames 60-90; óvulos 22-26; legume, velutino, ápice agudo; sementes elipsóides 8. I. rubiginosa

1.Inga alba (Sw.) Willd., Sp. Pl. 4: 1013. 1806.

Fig. 1

Árvore até $13 \mathrm{~m}$ de alt. Ramos cilíndricos, puberulentos. Estípulas $2-5 \mathrm{~mm}$ compr., oblongas, puberulentas, caducas. Pecíolos 0,6-3 cm compr., semicilíndricos, não alados, puberulentos. Nectários foliares 1-2 mm diâm., pateliformes ou ciatiformes, sésseis. Raque 2,5-8,7 cm compr., canaliculada ou plana, alada (ala, 2-3 mm larg.), puberulenta. Folhas 36jugas; folíolos 2-12×1-5,5 cm, cartáceos, discolores, glabros a ligeiramente puberulentos, elípticos a lanceolados, ápice agudo ou atenuado, base aguda a obtusa, venação eucampdódroma a broquidódroma, nervuras secundárias 5-9 pares, ascendentes. Inflorescências espiciformes, axilares; pedúnculos 0,3 $2 \mathrm{~cm}$ compr., planos a cilíndricos, puberulentos; brácteas 0,5-1,5 mm compr., espatuladas, puberulentas, caducas. Flores sésseis; cálice 0,7-1,5 mm compr., cupuliforme, lobos puberulentos; corola $2-4,5 \mathrm{~mm}$ compr., infundibuliforme, lobos puberulentos; tubo estaminal 6-9 mm compr., longamente exserto, estames 28-42, porção livre dos filetes 4-6 $\mathrm{mm}$ compr.; ovário 1-2 $\mathrm{mm}$ compr., elipsóide, glabro; estilete filiforme, igualando ou excedendo os estames; estigma globoso; óvulos 16-18. Legume 8-22 × 1,3-2 ×0,4-0,6 cm, reto ou curvado, convexo, castanho, com nervações reticulares proeminentes, não sulcado, coriáceo, glabro, ápice arredondado, base aguda, margens espessas e onduladas, apiculado, não estipitado. Sementes $0,7-$ $1,2 \times 0,5-0,7 \mathrm{~cm}$, oblongóides, lisas, glabras.

Material examinado: Coari, Base de Operação Geólogo Pedro de Moura, clareira próxima ao rio Urucu, 26.I.2007, fr., E.S.C. Gurgel et al. 530 (MG); 23.IX.2008, fl., J.S. Sousa et al. 85 (MG).

Espécies distribuem-se no México, Nicarágua, Costa Rica, Panamá, Colômbia, Venezuela, Bolívia, Equador, Guiana, Guiana Francesa, Peru e Brasil, ocorrendo nos estados do AP, RR, AM e PA (Sousa 

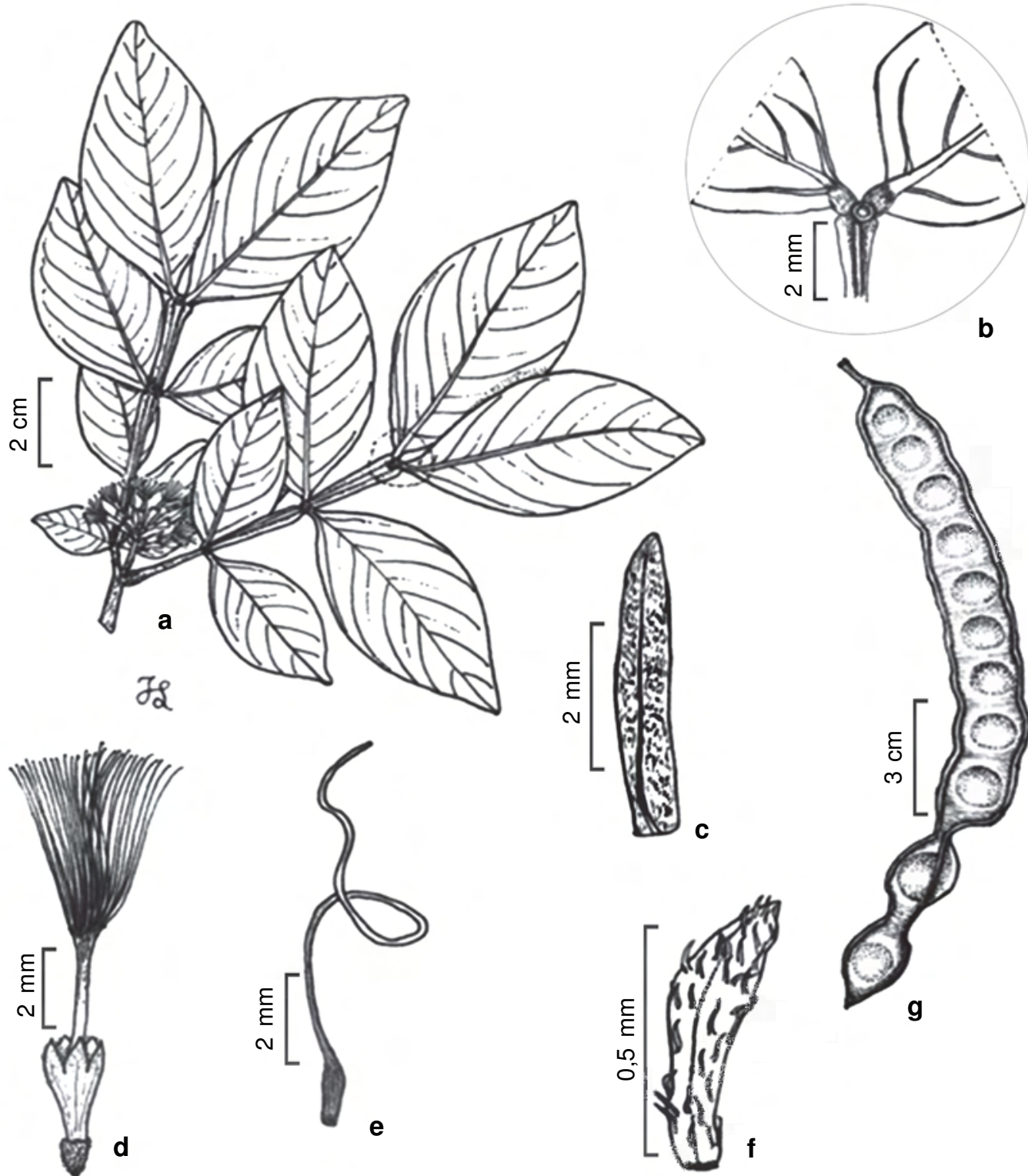

b
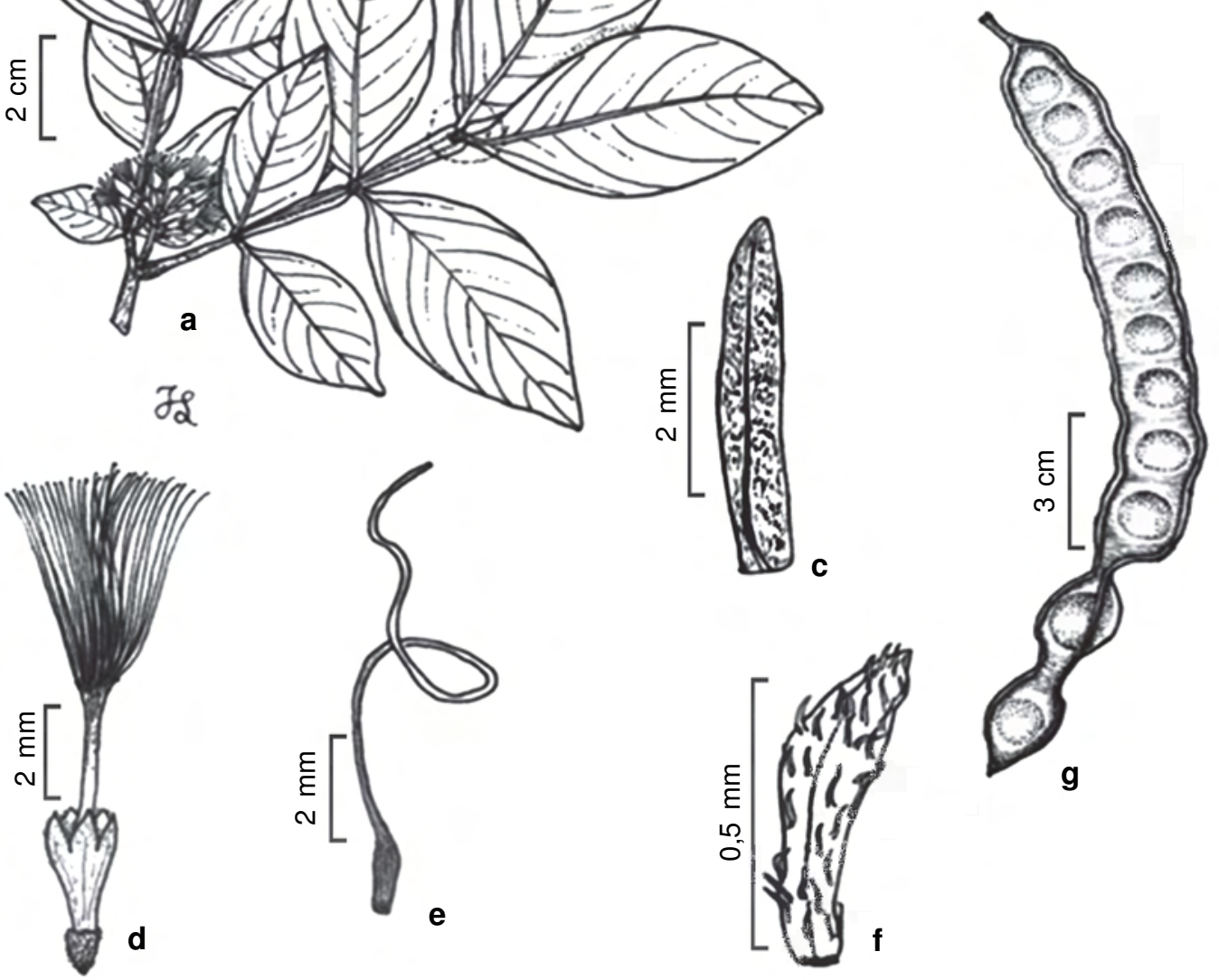

Figura 1 - Inga alba (Sw.) Willd. - a. ramo florido; b. nectário foliar; c. estípula; d. flor; e. gineceu; f. bráctea; g. fruto. Figure 1 - Inga alba (Sw.) Willd. - a. flowering branch; b. foliar nectary; c. stipule; d. flower; e. gynoecium; f. bract; g. fruit.

1993), além do AC, RO, MA, CE, GO e DF. Na província petrolífera de Urucu, ocorre nas clareiras da floresta de terra firme e próximas aos rios.

Entre as demais espécies da seção Bourgonia Benth. citadas neste trabalho (I. laurina I. pezizifera), I. alba distingui-se por apresentar nectários foliares pateliformes ou ciatiformes, raque canaliculada ou plana com ala 2-3 mm larg. e tubo estaminal 6-9 mm compr. Nessa seção, a espécie se destaca por ser a única na área, que apresenta folíolos de menores tamanhos (2$12 \times 1-5,5 \mathrm{~cm})$, dispostos em 3 a 6 jugas.
2. Inga calantha Ducke, Arch. Jard. Bot. Rio de Janeiro 4: 18. 1925.

Fig. 2

Árvore até $15 \mathrm{~m}$ de alt. Ramos angulosos, velutinos. Estípulas $2-3 \mathrm{~mm}$ compr., ovais, velutinas, caducas. Pecíolos 1,1-2 cm compr., cilíndricos, não alados, velutinos. Nectários foliares 0,5-1 mm diâm., cupuliformes, estipitados. Raque 8,5-14 cm compr., cilíndrica, alada (ala 1,4-2,2 cm larg.), velutina. Folhas 3-4 jugas; folíolos 4,4-20 × 2,5-10,5 cm, coriáceos, concolores, velutinos, elípticos ou ovais, ápice atenuado, base arredondada ou assimétrica, venação 


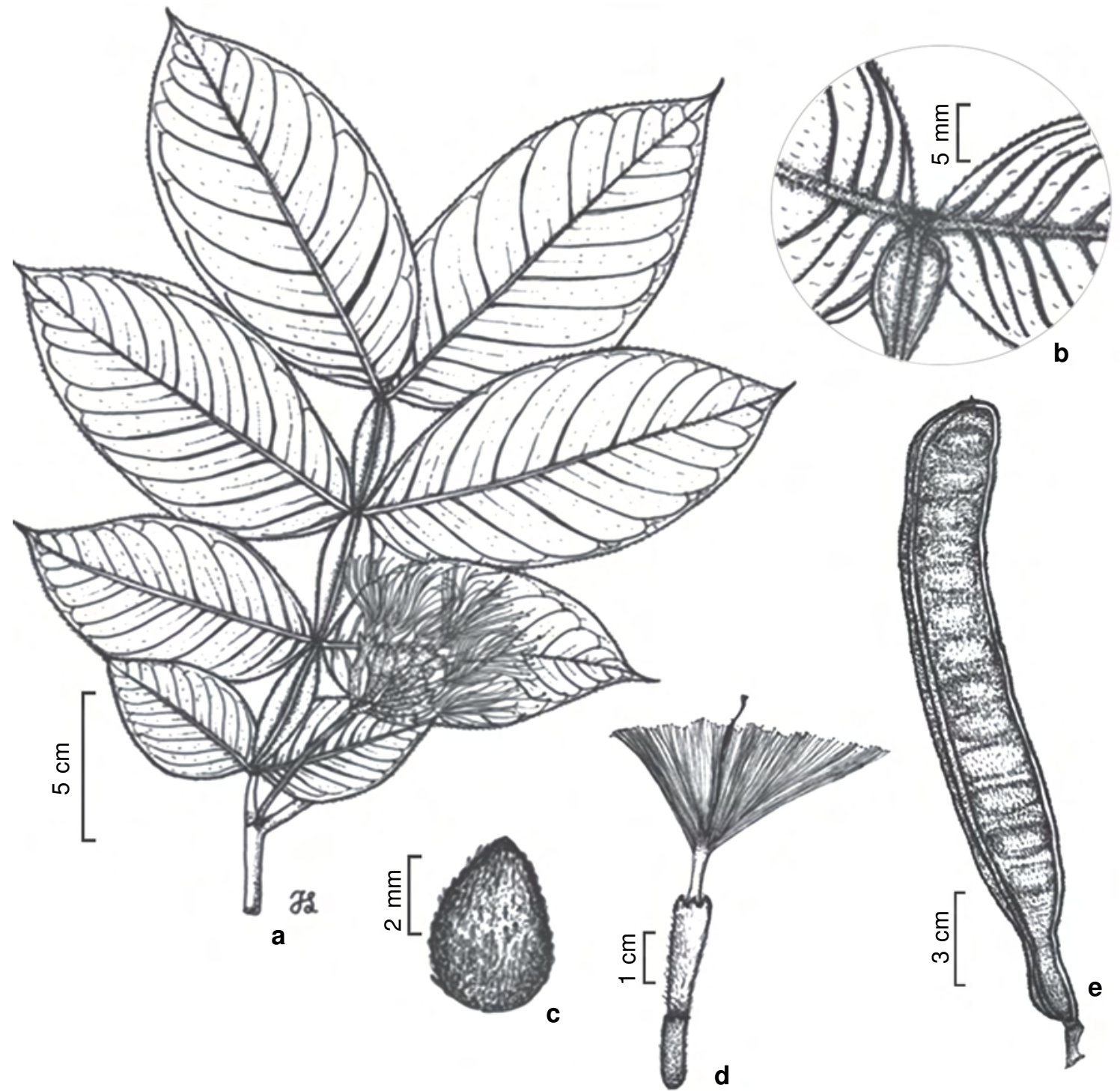

Figura 2 - Inga calantha Ducke - a. ramo florido; b. nectário foliar; c. estípula; d. flor; e. fruto.

Figure 2 - Inga calantha Ducke - a. flowering branch; b. foliar nectary; c. stipule; d. flower; e. fruit.

eucampdódroma a broquidódroma, nervuras secundárias 10-13 pares, convergentes e arqueadas. Inflorescências espiciformes, axilares; pedúnculos 4 $5 \mathrm{~cm}$ compr., cilíndricos, velutinos; brácteas caducas . Flores sésseis; cálice 1,2-1,6 cm compr., tubular, lobos tomentosos; corola 4-5 cm compr., tubular, lobos vilosos; tubo estaminal 4,7-6 cm compr., exserto, estames 60-80, porção livre dos filetes 2,5-4,2 cm compr.; ovário 0,5-1 cm compr., elipsóide, glabro; estilete filiforme, excedendo os estames; estigma funiforme; óvulos 22-30. Legume 9,9-21 ×2,5-3×1,1-1,8 cm, reto a curvado, plano a levemente convexo, verde a ferrugíneo, sem nervações transversais, não sulcado, coriáceo, densamente híspido, ápice arredondado, base aguda a arredondada, margens espessas e lineares, apiculado, estipitado. Sementes 1,5-2 × 0,6-1 cm, oblongóides a elipsóides, lisas, glabras.

Material examinado: Coari, Base de Operação Geólogo Pedro de Moura, clareira em floresta de terra firme, 21.IX.2008, fl., J.S. Sousa et al. 63 (MG); 21.XII.2009, fr., J.S. Sousa et al. 156 (MG); 21.XII.2009, fr., M.M. Félix-da-Silva et al. 608 (MG).

Espécies ocorrem no Brasil, PA, ao longo do Tapajós (Pennington 1997) e também no AM. Na área, a espécie é encontrada em clareiras das florestas de terra firme. 
Inga calantha assemelha-se morfologicamente com I. rubiginosa, da qual difere por apresentar ramos angulosos, raque alada e nectários foliares cupuliformes. $\mathrm{Na}$ área de estudo, a espécie é facilmente identificada por ser a única que possui maior tubo estaminal $(4,7-$ $6 \mathrm{~cm}$ compr.) e legume densamente híspido.

3. Inga edulis Mart., Flora 20 (2): Beibl. 113-114. 1837.

Fig. 3

Árvore até $25 \mathrm{~m}$ de alt. Ramos semicilíndricos, puberulentos. Estípulas 2-6 mm compr., oblongas ou lanceoladas, puberulentas, caducas. Pecíolos $2-5 \mathrm{~cm}$ compr., cilíndricos, não alados, puberulentos. Nectários foliares 2-3 mm diâm., reniformes, sésseis. Raque 7$20 \mathrm{~cm}$ compr., cilíndrica, alada (ala até $1,6 \mathrm{~cm}$ larg.), puberulenta. Folhas 4-6 jugas; folíolos 3,8-19×1,9$8,9 \mathrm{~cm}$, cartáceos, discolores, puberulentos, elípticos, obovais ou ovais, ápice agudo, obtuso, cuspidado ou atenuado, base arredondada, truncada ou assimétrica, venação eucampdódroma a broquidódroma, nervuras secundárias 6-20 pares, paralelas a convergentes. Inflorescências espiciformes, axilares; pedúnculos

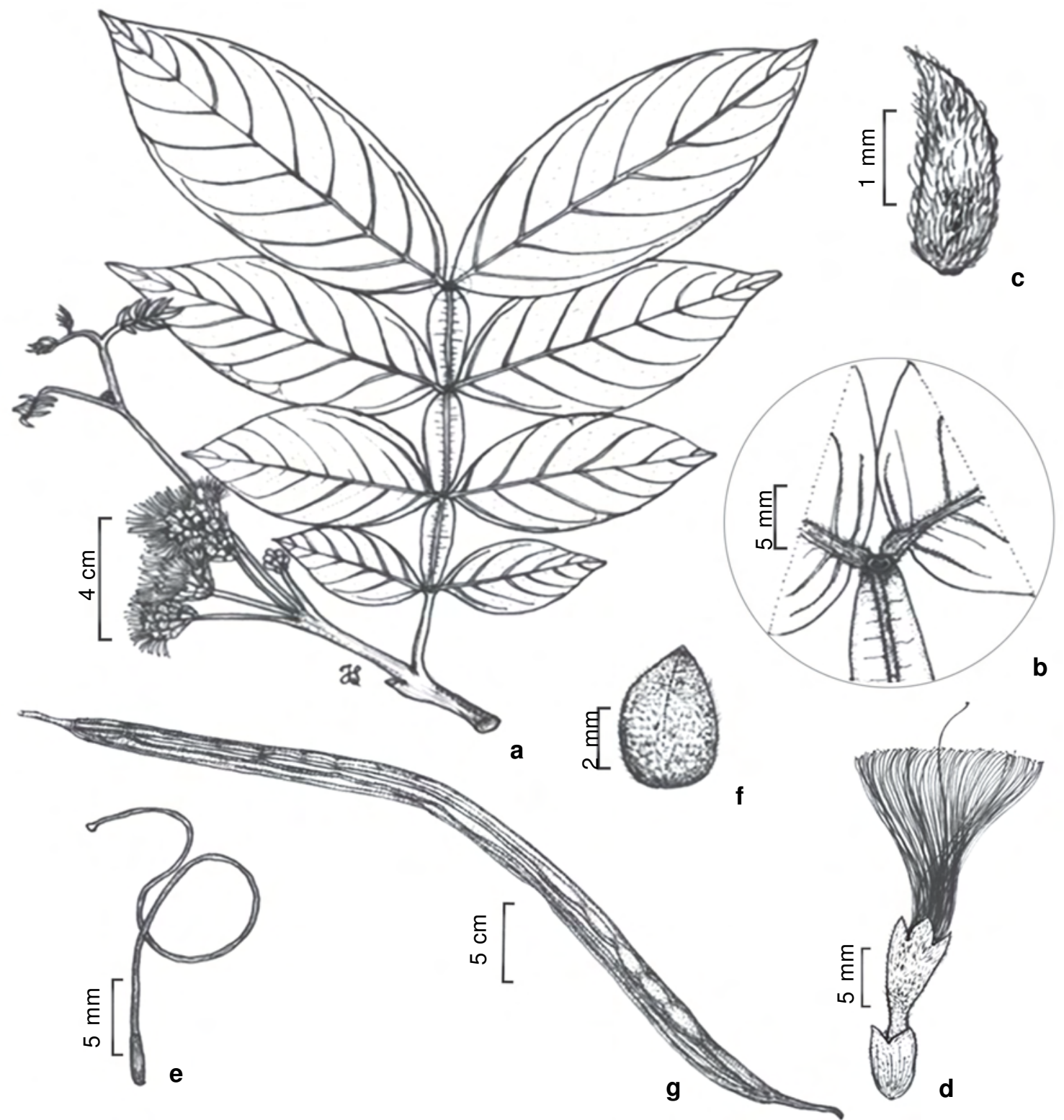

Figura 3 - Inga edulis Mart. - a. ramo florido; b. nectário foliar; c. estípula; d. flor; e. gineceu; f. bráctea; g. fruto. Figure 3 - Inga edulis Mart. - a. flowering branch; b. foliar nectary; c. stipule; d. flower; e. gynoecium; f. bract; g. fruit. 
1-5 cm compr., cilíndricos, puberulentos; brácteas $0,3-$ $1 \mathrm{~cm}$ compr., ovais, puberulentas, caducas. Flores sésseis; cálice 4-9 $\mathrm{mm}$ compr., tubular, lobos puberulentos; corola 0,9-1,9 cm compr., tubular ou infundibuliforme, lobos seríceo-vilosos; tubo estaminal 1-2 cm compr., incluso ou exserto, estames 55-100, porção livre dos filetes 1,5-3 cm compr.; ovário 2-4,5 mm compr., oblongo, glabro; estilete filiforme, excedendo os estames; estigma cupuliforme; óvulos 20-30. Folículo 30-180 $\times 2-5 \mathrm{~cm}$, reto, curvado ou torcido, convexo, verde a castanho, com nervações longitudinais, profundamente sulcado, coriáceo, esparsamente tomentoso, ápice agudo a rostrado, base arredondada, margens espessas e lobadas, não apiculado, estipitado. Sementes $2-3 \times 1-1,5 \mathrm{~cm}$, elipsóides, lisas, glabras.

Material examinado: Coari, Base de Operação Geólogo Pedro de Moura, clareira próxima a capoeira, 20.IX.2008, fl. e fr., J.S. Sousa et al. 55 (MG); 20.XII.2009, fl. e fr., J.S. Sousa et al. $142(\mathrm{MG})$; clareira próxima à margem do rio, 20.XII.2009, fl. e fr., M.M. Félix-da-Silva et al. 594 (MG); 20.XII.2009, fl. e fr., S. Maciel et al. 1446 (MG).

A espécie ocorre na Colômbia, América do Sul tropical, leste dos Andes, estendendo-se até o noroeste da Argentina, sendo no Brasil encontrada ao longo da costa atlântica (Pennington 1997). Na base petrolífera de Urucu, a espécie é encontrada em clareiras próximas à capoeiras e rios.

Inga edulis difere-se das demais cogenéricas aqui tratadas, principalmente, por apresentar nectários foliares reniformes, folículos de 30-180 cm compr., com nervações longitudinais, profundamente sulcados e com margens lobadas, os quais são caracteres seguros para sua identificação.

\section{Inga heterophylla Willd., Sp. Pl. 4(2): 1020. 1806.}

Fig. 4

Árvore de até $8 \mathrm{~m}$ de alt.. Ramos cilíndricos, glabros ou pubescentes. Estípulas 1,5-4 mm compr., lanceoladas, glabras, caducas. Pecíolos 0,3-1,5 cm compr., cilíndricos, canaliculados na face superior, alados somente no ápice, glabros. Nectários foliares 0,5-1 mm diâm., pateliformes, estipitados até $1 \mathrm{~mm}$ compr. Raque 1,5-4,5 cm compr., cilíndrica à canaliculada, estreitamente alada (ala até $1 \mathrm{~mm}$ larg.), glabra. Folhas 1-4 jugas; folíolos 2-12×0,9-5 cm, cartáceos, concolores, glabros, elípticos à elipticolanceolados, ápice acuminado, base cuneada ou atenuada, venação eucampdódroma a broquidódroma, nervuras secundárias 6-9 pares, convergentearqueados. Inflorescências umbeliformes, axilares; pedúnculos 0,9-5 cm compr., cilíndricos, glabros ou puberulentos; brácteas $0,7-1 \mathrm{~mm}$ compr., linear- espatuladas, puberulentas, caducas. Flores pediceladas; cálice 1-2 mm compr., tubular, lobos glabros a puberulentos; corola 3-7 $\mathrm{mm}$ compr., tubular, lobos glabros; tubo estaminal $0,5-1 \mathrm{~cm}$ compr., exserto, estames 30-55; porção livre dos filetes $0,8-1 \mathrm{~cm}$ compr.; ovário $0,8-2 \mathrm{~mm}$ compr., elipsóide, glabro, estilete filiforme, excedendo os estames, estigma globoso. Legume nucóide 7-20× $1,2-1,5 \times 0,9-1,2 \mathrm{~cm}$, reto ou curvado, plano a convexo, castanho, coriáceo, glabro, ápice e base agudos, margem delgada e ondulada, sem nervuras, não sulcado, apiculado, estipitado. Sementes 0,9$1,2 \mathrm{~cm}$, elipsóides, lisas, glabras.

Material examinado: Coari, Base de Operação Geólogo Pedro de Moura, clareira em floresta de terra firme, 19.V.2008, fl., E.S.C. Gurgel et al. 777 (MG); 24.IX.2008, fl., J.S. Sousa et al. 108 (MG); 21.XII.2009, fr., J.S. Sousa et al. 160 (MG).

A espécie ocorre no Panamá, Colômbia, Trinidad, Guiana, Suriname, Guiana Francesa, Equador, Peru, Brasil, Bolívia (Barneby et al. 2001) e Venezuela (Sousa 1993). Na área, a espécie é encontrada nas clareiras da floresta de terra firme.

Segundo Sousa (1993) Inga heterophylla possui inflorescências que variam de racemo a umbela, porém nas amostras da base petrolífera de Urucu foram observadas somente inflorescências umbeliformes, que juntamente com o pecíolo alado no ápice são diagnósticos para a identificação da espécie. A espécie relaciona-se morfologicamente com I. sertulifera, da qual difere-se pela raque estreitamente alada (até $1 \mathrm{~mm}$ larg.) e nectário foliar estipitado (até $1 \mathrm{~mm}$ compr.), concordando com Pennington (1997).

5. Inga laurina (Sw.) Willd., Sp. Pl. 4: 1018. 1806.

Fig. 5

Árvore até $15 \mathrm{~m}$ de alt. Ramos cilíndricos, glabros ou puberulentos. Estípulas 1,5-4 mm compr., lanceoladas, puberulentas ou glabras, caducas. Pecíolos 1-2 cm compr., cilíndricos, não alados, glabros ou puberulentos. Nectários foliares 0,5-2 mm diâm., cupuliformes, sésseis. Raque 2-4 cm compr., cilíndrica, alada (ala, 0,5-2,5 cmlarg.), glabra ou puberulenta. Folhas 2-3 jugas; folíolos 6,7-17 × 1,9-7,2 cm, cartáceos, concolores, glabros, elípticos, ápice atenuado, base aguda, venação eucampdódroma a broquidódroma, nervuras secundárias 5-11 pares, convergentes e arqueadas. Inflorescências espiciformes, axilares; pedúnculos 0,5-3 cm compr., cilíndricos, puberulentos; brácteas 1-2 mm compr., ovais, puberulentas, caducas. Flores sésseis; cálice 0,7-2 mm compr., cupuliforme, lobos puberulentos; corola 3-5,5 mm compr., 
infundibuliforme, lobos puberulentos; tubo estaminal 4-6,5 mm compr., exserto, estames $28-60$, porção livre dos filetes 5-10 mm compr.; ovário 1,5-2 mm compr., elipsóide, glabro; estilete filiforme, excedendo os estames; estigma globoso; óvulos 10-20. Legume 3,7$15,2 \times 1,2-2,5 \times 0,3-0,7 \mathrm{~cm}$, reto ou curvado, convexo, castanho, com nervações transversais proeminentes, não sulcado, coriáceo, glabro, ápice e base agudos a obtusos, margens espessas e onduladas, apiculado, estipitado. Sementes $0,8-1,2 \times 0,4-0,6 \mathrm{~cm}$, oblongóides a obovóides, rugosas, glabras.

Material examinado: Coari, Base de Operação Geólogo Pedro de Moura, clareira próxima ao rio Urucu, 1.VII.2005, fl., E.S.C. Gurgel et al. 346 (MG); 29.I.2007, fr., E.S.C. Gurgel et al. 579 (MG); clareira em capoeira, 16.V.2008, fl., E.S.C. Gurgel et al. 606 (MG); clareira próxima ao rio Urucu, 23.IX.2008, fl., J.S. Sousa et al. 83 (MG); clareira em capoeira, 21.XII.2009, fr., J.S. Sousa et al. 161 (MG).

Espécie com distribuição ampla, ocorrendo do noroeste do México $\left(21^{\circ} \mathrm{N}\right)$, em quase toda a América Central, América do Sul, até o Paraguai e Norte da Argentina, incluindo nas regiões montanhosas da Costa Rica, Panamá e América do Sul, em altitudes de até $1500 \mathrm{~m}$, sendo relativamente tolerante às regiões de cerrado e campos secos (Pennington 1997). No Brasil, estende-se desde a região amazônica até o estado do Paraná (Sousa 1993; Garcia 1998; Lorenzi 2002). Na área de estudo, a espécie foi encontrada nas clareiras de capoeira e nas áreas próximas às margens dos rios.
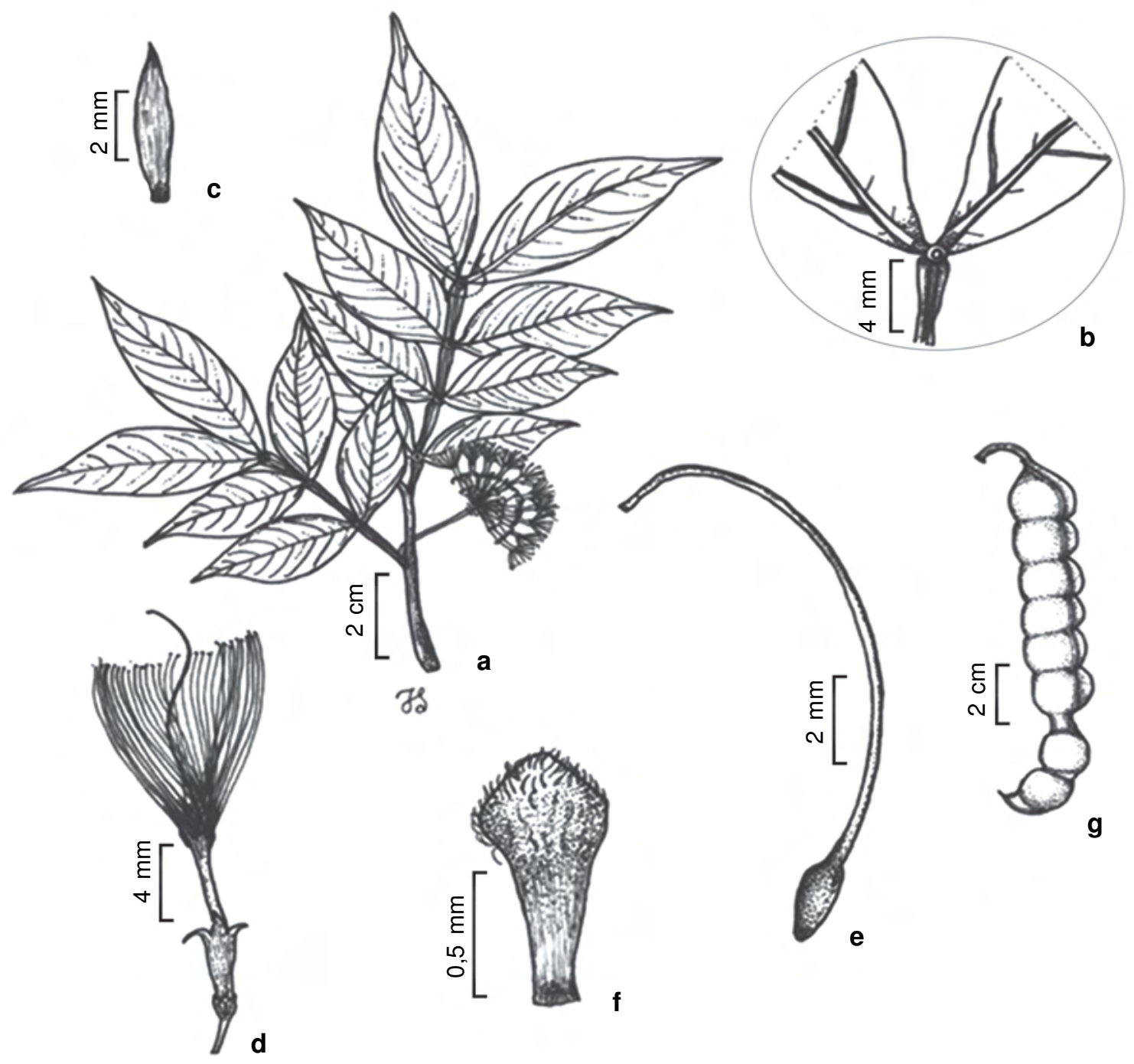

Figura 4 - Inga heterophylla Willd. - a. ramo florido; b. nectário foliar; c. estípula; d. flor; e. gineceu; f. bráctea; g. fruto. Figure 4 - Inga heterophylla Willd. - a. flowering branch; b. foliar nectary; c. stipule; d. flower; e. gynoecium; f. bract; g. fruit. 
Inga laurina e I. stenoptera são as únicas espécies, entre as estudadas, a apresentarem folhas com 2 a 3 jugas; no entanto, a primeira caracteriza-se pelas nervuras secundárias de 511 pares, brácteas ovais, cálice cupuliforme, tubo estaminal 4-6,5 $\mathrm{mm}$ compr., estigma globoso, legume apiculado; enquanto a segunda apresenta nervuras secundárias 9-12 pares, brácteas elípticas, cálice tubular, tubo estaminal $1,4-2 \mathrm{~cm}$ compr., estigma cupular e legume não apiculado.
6. Inga nobilis Willd. subsp. nobilis, Enum. Hort. Berol. 2: 1047. 1809.

Fig. 6

Árvore até $6 \mathrm{~m}$ de alt. Ramos cilíndricos, tomentosos. Estípulas 0,5-4 mm compr., elípticas, pubescentes, persistentes. Pecíolos 0,5-2 cm compr., cilíndricos, não alados, tomentosos. Nectários foliares 1-2,5 mm diâm., pateliformes, sésseis. Raque 3,5$6,4 \mathrm{~cm}$ compr., cilíndrica a canaliculada, não alada, tomentosa. Folhas 3-5 jugas; folíolos 3,4-18,1 × 1,4$6 \mathrm{~cm}$, coriáceos, concolores, glabros a esparsamente pubescentes, principalmente na nervura central,

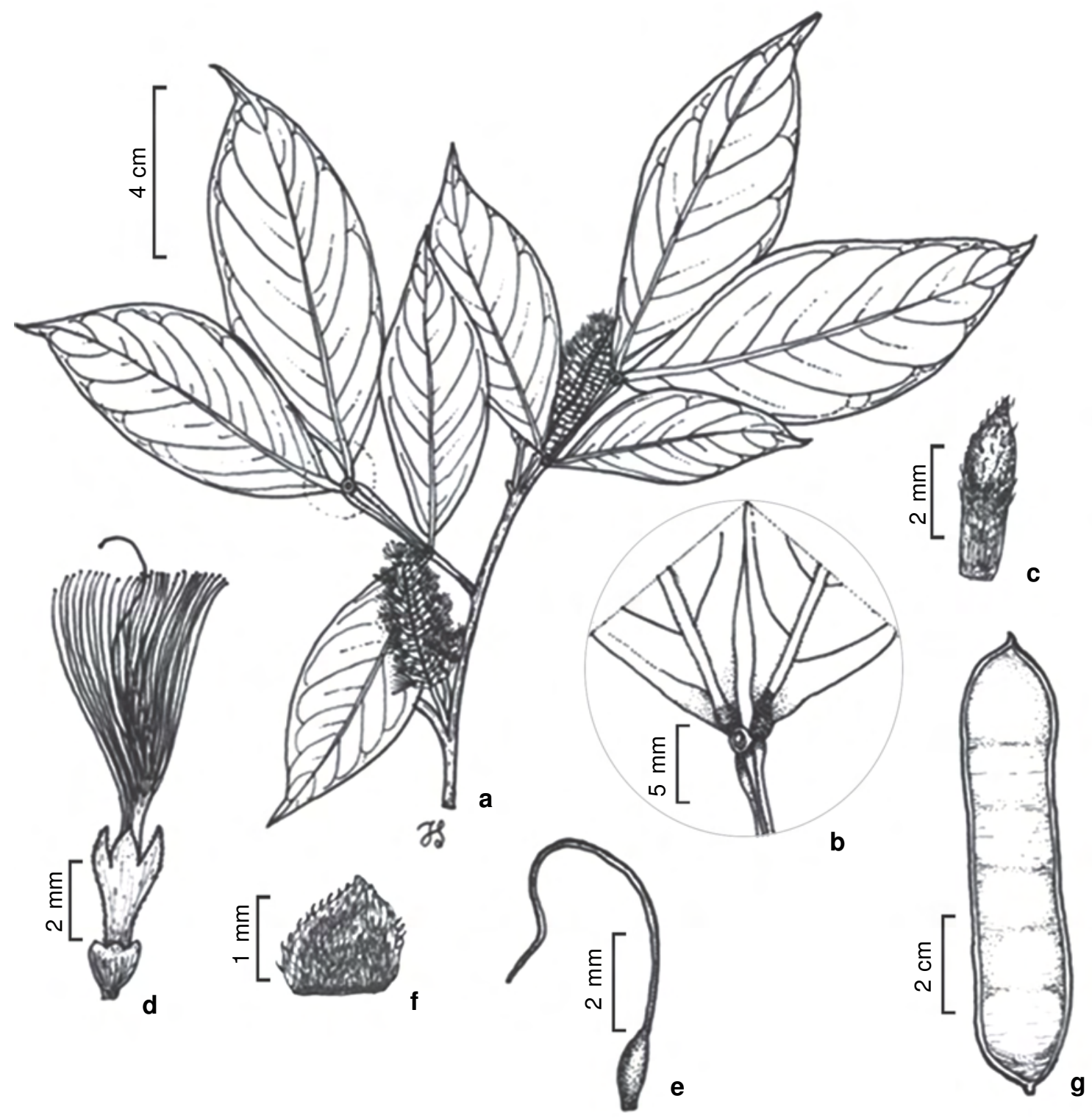

Figura 5 - Inga laurina (Sw.) Willd. - a. ramo florido; b. nectário foliar; c. estípula; d. flor; e. gineceu; f. bráctea; g. fruto. Figure 5 - Inga laurina (Sw.) Willd. - a. flowering branch; b. foliar nectary; c. stipule; d. flower; e. gynoecium; f. bract; g. fruit. 


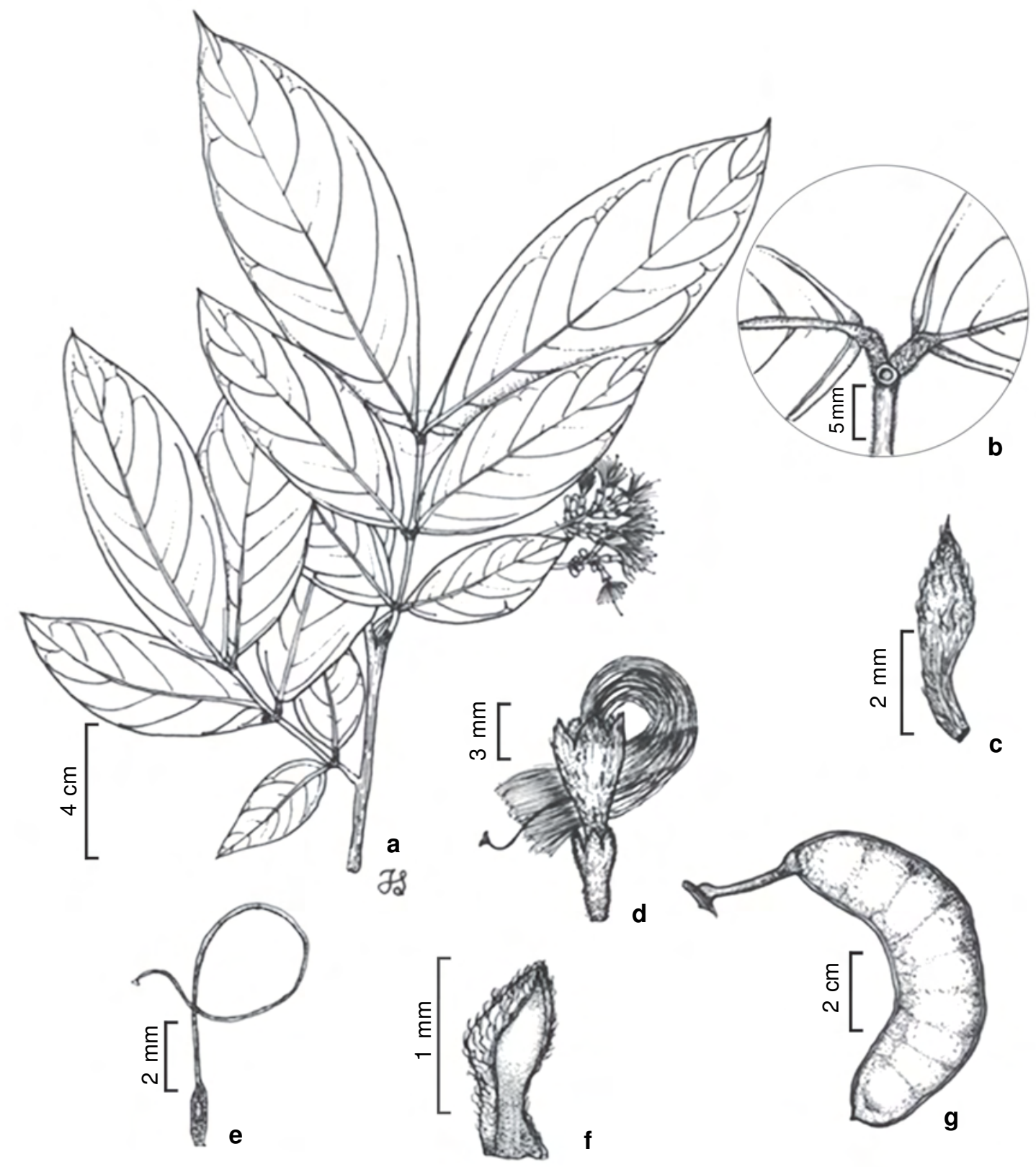

Figura 6 - Inga nobilis Willd. subsp. nobilis - a. ramo florido; b. nectário foliar; c. estípula; d. flor; e. gineceu; f. bráctea.; g. fruto. Figure 6 - Inga nobilis Willd. subsp. nobilis - a. flowering branch; b. foliar nectary; c. stipule; d. flower; e. gynoecium; f. bract; g. fruit.

elípticos, oblongo-elípticos, lanceolados ou ovais, ápice atenuado a agudo, base aguda, cuneada ou obtusa, venação eucampdódroma a broquidódroma, nervuras secundárias 5-10 pares, ascendentes. Inflorescências espiciformes, axilares; pedúnculos $1,9-8 \mathrm{~cm}$ compr., planos a cilíndricos, tomentosos; brácteas 1-2 mm compr., espatuladas, tomentosas, persistentes. Flores sésseis; cálice 3-7 mm compr., infundibuliforme, lobos pubescentes; corola 0,6-
$1,1 \mathrm{~cm}$ compr., infundibuliforme, lobos seríceos a vilosos; tubo estaminal $0,8-1,2 \mathrm{~cm}$ compr., incluso ou exserto, estames 38-60, porção livre dos filetes 1,22,5 cm compr.; ovário 1,5-2,5 mm compr., oblongo a oblanceolado, glabro a ligeiramente puberulentos; estilete filiforme, excedendo os estames; estigma expandido; óvulos 12-16. Legume nucóide 9,1-14× $1,5-3,5 \times 0,7-1 \mathrm{~cm}$, reto a ligeiramente curvado, convexo, castanho, com nervações transversais 
proeminentes, não sulcado, coriáceo, puberulento, ápice e base obtusos ou arredondados, margens espessas e onduladas, apiculado, estipitado. Sementes 0,9-1,6×0,4-0,7 cm, oblongóides, lisas, glabras.

Material examinado: Coari, Base de Operação Geólogo Pedro de Moura, clareira à margem do rio Urucu, 26.I.2007, fl., E.S.C. Gurgel et al. 533 (MG) ; 28.I.2007, fl. e fr., E.S.C. Gurgel et al. 559 (MG); 12.III.2007, fl., R. Lavareda et al. 41 (MG); 21.XII.2009, fr., J.S. Sousa et al. 158(MG).

O táxon ocorre na Amazônia, Andes, desde a Colômbia até a Bolívia, Venezuela, Guianas e regiões amazônica e central do Brasil (Pennington 1997). Na base petrolífera de Urucu, a espécie é encontrada em clareiras próxima a mata ciliar.
Inga nobilis Willd. subsp. nobilis diferencia-se de Inga nobilis Willd. subsp. quaternata (Poepp. \& Endl.) T.D. Penn. por apresentar espigas congestas, raque floral não expandida e flores sésseis (Pennington 1997). Na área de estudo, o táxon em questãoé o único que apresenta ramos tomentosos, estípulas elípticas, cálice infundibuliforme e legume nucóide puberulento.

\section{Inga pezizifera Benth., London J. Bot. 4:} 587. 1845.

Fig. 7

Árvore até $15 \mathrm{~m}$ de alt. Ramos semicilíndricos, puberulentos. Estípulas 2,5-9 mm compr., oblongas a lanceoladas, puberulentas, caducas. Pecíolos $2-4 \mathrm{~cm}$ compr., cilíndricos a canaliculados, não alados,

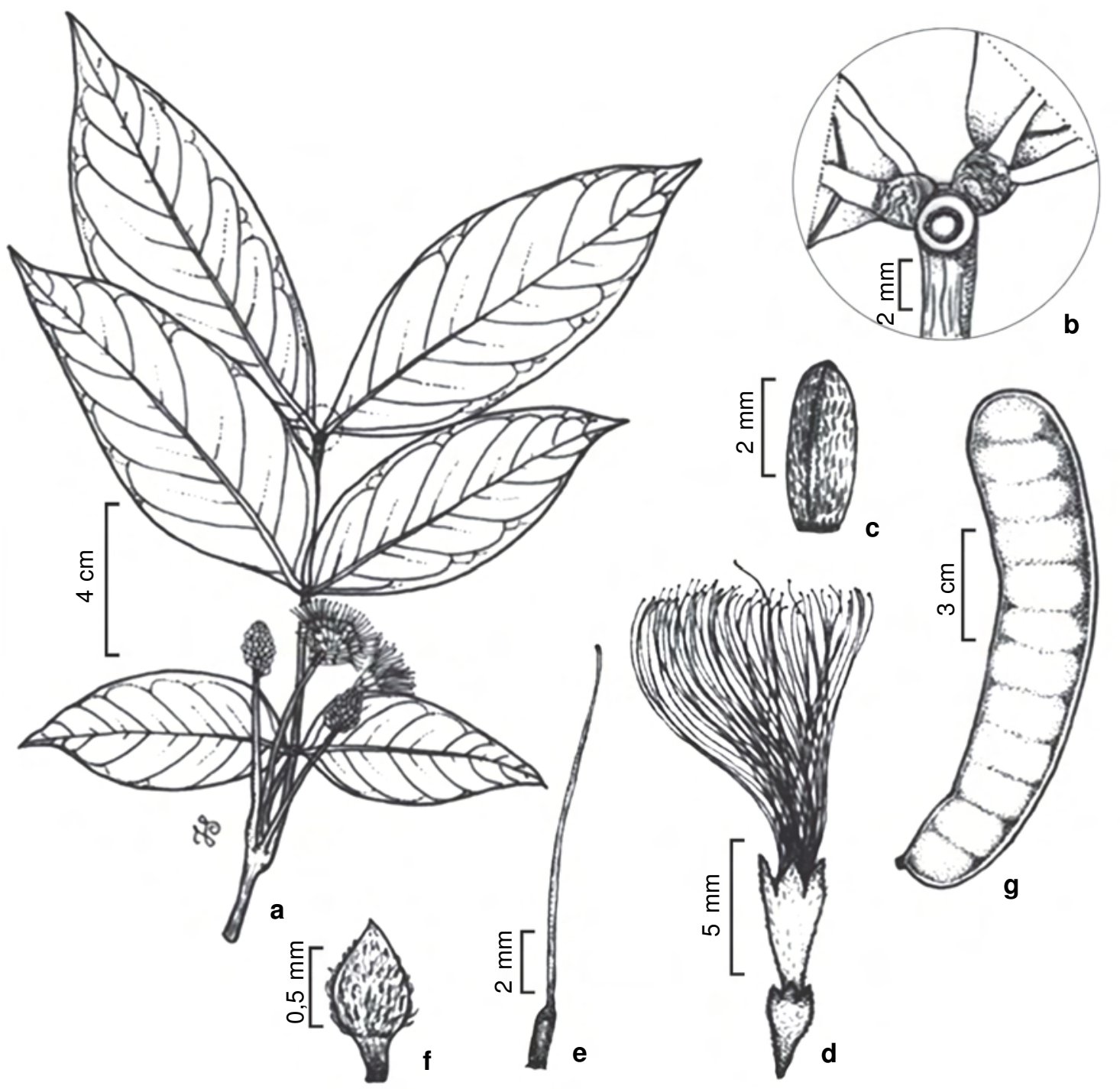

Figura 7 - Inga pezizifera Benth. - a. ramo florido; b. nectário foliar; c. estípula; d. flor; e. gineceu; f. bráctea; g. fruto. Figure 7 - Inga pezizifera Benth. - a. flowering branch; b. foliar nectary; c. stipule; d. flower; e. gynoecium; f. bract; g. fruit. 
puberulentos. Nectários foliares 1,5-3 mm diâm., cupuliformes, sésseis ou com estipe 0,5-1 mm compr. Raque 6,3-14 cm compr., canaliculada, não alada, puberulenta. Folhas 3-6 jugas; folíolos 5,1-19 cm $\times$ 2,4-8,1 cm, cartáceos, discolores, glabros ou esparsamente puberulentos em ambas as faces, elípticos, lanceolados ou ovais, ápice atenuado, base aguda ou arredondada, venação eucampdódroma a broquidódroma, nervuras secundárias 7-11 pares, convergentes e arqueadas. Inflorescências racemosas, axilares; pedúnculos 2,5-6 cm compr., cilíndricos, puberulentos; brácteas $0,5-1,5 \mathrm{~mm}$ compr., espatuladas, puberulentas, caducas. Flores pediceladas; cálice 1-2,5 mm compr., cupuliforme ou tubular, lobos puberulentos; corola 5,5-7 mm compr., infundibuliforme, lobos puberulentos; tubo estaminal 5,5-7 mm compr., estames 46-55, porção livre dos filetes 6-10 mm compr.; ovário 1-2 mm compr., oblongo, glabro; estilete filiforme, excedendo os estames; estigma globoso; óvulos 16-18. Legume 13$20 \times 1,8-4 \times 0,3-0,6 \mathrm{~cm}$, reto a curvado, convexo, castanho, sem nervações transversais, não sulcado, coriáceo, esparsamente puberulento, ápice e base arredondados, margens espessas e lineares, não apiculado, não estipitado. Sementes $0,9-2 \times 0,5-1 \mathrm{~cm}$, elipsóides, lisas, glabras.

Material examinado: Coari, Base de Operação Geólogo Pedro de Moura, clareira próxima à floresta de terra firme, 19.III.2007, fl. e fr., R. Lavareda et al. 94 (MG); clareira às margem do rio Urucu, 21.XII.2009, fr., J.S. Sousa et al. 159 (MG).

A espécie ocorre da Costa Rica a Venezuela, Guianas, Amazônia brasileira e Equador (Pennington 1997). Na área estudada, pode ser encontrada nas clareiras da floresta de terra firme e naquelas próximas aos rios.

A espécie se destaca e pode ser facilmente reconhecida, quando comparada com as demais estudadas, por apresentar inflorescências racemosas e tubo estaminal igualando ao tamanho da corola.

\section{Inga rubiginosa (Rich.) DC., Prod. 2: 434. 1825.}

Fig. 8

Árvore até $18 \mathrm{~m}$ de alt. Ramos cilíndricos, velutinos. Estípulas 1,5-3 mm compr., ovais, velutinas, caducas. Pecíolos 1,3-3 cm compr., cilíndricos, não alados, velutinos. Nectários foliares 1,5-3 mm diâm., pateliformes, sésseis. Raque 7,6$13,5 \mathrm{~cm}$ compr., cilíndrica, não alada, velutina. Folhas 3-5 jugas; folíolos 5,9-21 ×3-12,5 cm, cartáceos, discolores, velutinos, elípticos ou ovais, ápice cuspidado ou agudo, base obtusa ou arredondada, venação eucampdódroma a broquidódroma, nervuras secundárias 8-13 pares, ascendentes. Inflorescências espiciformes, axilares; pedúnculos 0,9-3,5 cm compr., cilíndricos, velutinos; brácteas 1,5-3 mm compr., ovais, velutinas, caducas. Flores sésseis; cálice 4-7 mm compr., cupuliforme, lobos velutinos; corola 1,7-3,1 cm compr., tubular, lobos densamente vilosos; tubo estaminal 2-3,5 cm compr., incluso ou exserto, estames 60-90, porção livre dos filetes $2,8-5 \mathrm{~cm}$ compr.; ovário $3-4,5 \mathrm{~mm}$ compr., oblongo, glabro; estilete filiforme, excedendo os estames; estigma expandido; óvulos 22-26. Legume 9,5-30,5 × 1,6-2,9 ×0,4-0,9 cm, reto a curvado, planos, verde ou castanho, com nervações transversais, não sulcado, coriáceo, velutino, ápice agudo, base aguda a arredondada, margens espessas e onduladas, apiculado, não estipitado. Sementes 2,5-3,5 × 1,5-2,5 mm, elipsóides, lisas, glabras.

Material examinado: Coari, Base de Operação Geólogo Pedro de Moura, clareira próxima ao rio Urucu, 27.I.2007, fr., E.S.C. Gurgel et al. 546 (MG); clareira em mata de capoeira, 23.IX.2008, fl., J.S. Sousa et al. 91 (MG); 21.XII.2009, fr., J.S. Sousa et al. 157 (MG).

A espécie ocorre no Panamá, Colômbia, Guiana, Suriname, Guiana Francesa, Venezuela e Brasil (Barneby et al. 2001; Sousa 1993), ocorrendo nos estados AP, MA, PA (Sousa 1993), BA e AM, como um provável registro para a costa brasileira (Pennington 1997). Na base operacional geólogo Pedro de Moura, a espécieé muito comum nas clareiras às margens dos rios e nas próximas a capoeiras.

Inga rubiginosa assemelha-se morfologicamente a I. cayennensis Sagot ex Benth., da qual difere pelo indumento velutino mais curto, raque foliar cilíndricae nectários foliares sésseis (Pennington 1997). Esta espécie foi incluída por Bentham na seção Euinga Benth., entretanto Pennington (1997), analisando o fruto plano, colocou-a na seção Longiflorae (Benth.) T.D. Penn. Na área de estudo, a espécie é facilmente reconhecida por ser a única que apresenta frutos velutinos.

9. Inga stenoptera Benth., London J. Bot. 2: 143. 1840.

Fig. 9

Árvore até $8 \mathrm{~m}$ de alt. Ramos cilíndricos, glabros. Estípulas 2-4,5 mm compr., lanceoladas, esparsamente pubescentes, persistentes. Pecíolos 1-3,5 cm compr., semicilíndricos, alados ou não (ala, 3-4 mm larg.), glabros ou esparsamente pubescentes. Nectários foliares 1,5-3 mm diâm., cupuliformes, sésseis. Raque $2-5,7 \mathrm{~cm}$ compr., canaliculada ou cilíndrica, alada (ala, 3-5 mm larg.), glabra ou esparsamente pubescente. Folhas 2-3 
jugas; folíolos $5-20 \mathrm{~cm} \times 2-8 \mathrm{~cm}$, cartáceos, concolores, glabros, elípticos, ápice atenuado, base aguda a arredondada, venação eucampdódroma, nervuras secundárias 9-12 pares, paralelas a ascendentes. Inflorescências espiciformes, axilares; pedúnculos 2-6 cm compr., cilíndricos, esparsamente pubescente; brácteas $1-4 \mathrm{~mm}$ compr., elípticas, pubescentes, persistentes. Flores sésseis; cálice 3-5 mm compr., tubular, lobos pubescentes; corola 1,1-1,7 cm compr., infundibuliforme, lobos seríceos a vilosos; tubo estaminal 1,4-2 cm compr., exserto, estames 40-62, porção livre do filete 12 cm compr.; ovário 1,5-2,5 mm compr., elipsóide, glabro; estilete filiforme, excedendo os estames; estigma cupular; óvulos 12-25. Legume 9-27×2$2,9 \times 0,6-0,9 \mathrm{~cm}$, reto ou curvado, convexo, castanho, com nervações transversais proeminentes, não sulcado, coriáceo a lenhoso, glabro, ápice e base agudos ou arredondados, margens espessas e onduladas, não apiculado, não estipitado. Sementes 0,9-1,6 × 0,5-0,9 cm, oblongóides a elipsóides, lisas, glabras.

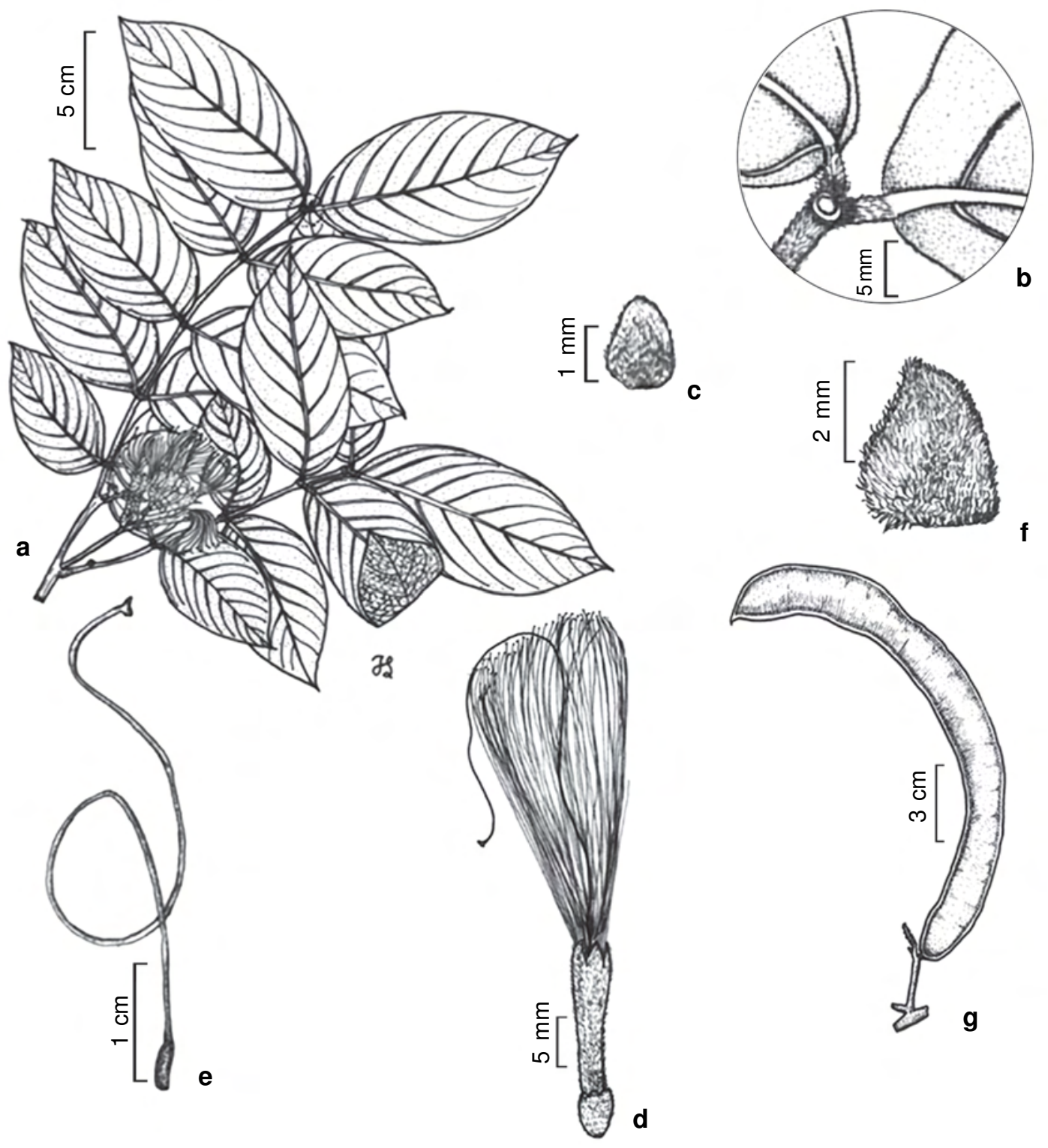

Figura 8 - Inga rubiginosa (Rich.) DC. - a. ramo florido; b. nectário foliar; c. estípula; d. flor; e. gineceu; f. bráctea.; g. fruto. Figure 8 - Inga rubiginosa (Rich.) DC. - a. flowering branch; b. foliar nectary; c. stipule; d. flower; e. gynoecium; f. bract; g. fruit. 


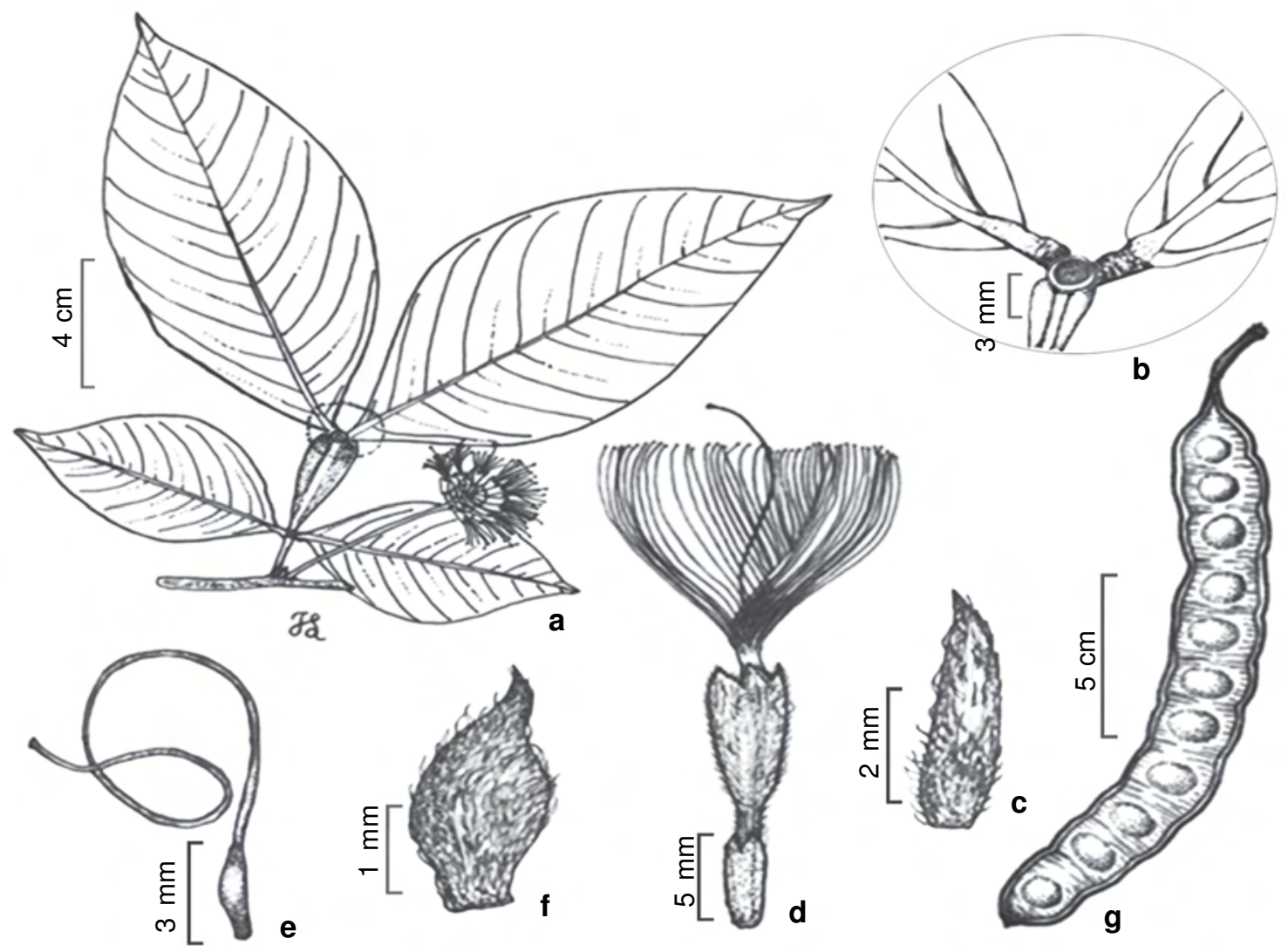

Figura 9 - Inga stenoptera Benth. - a. ramo florido; b. nectário foliar; c. estípula; d. flor; e. gineceu; f. bráctea.; g. fruto. Figure 9 - Inga stenoptera Benth. - a. flowering branch; b. foliar nectary; c. stipule; d. flower; e. gynoecium; f. bract; g. fruit.

Material examinado: Coari, Base de Operação Geólogo Pedro de Moura, clareira próxima ao rio Urucu, 25.I.2007, fr., E.S.C. Gurgel et al. 521 (MG); 28.I.2007, fr., E.S.C. Gurgel et al. 562 (MG); 20.IX.2008, fl., J.S. Sousa et al. 53 (MG).

A espécie ocorre no oeste da América do Sul (Colômbia a Bolívia), Venezuela e Amazônia brasileira (Pennington 1997). Na área estudada, a espécie é frequentemente encontrada nas clareiras às margens dos rios.

Inga stenoptera pode ser confundida com I. laurina por apresentar semelhança, principalmente, no número de jugas, forma dos folíolos, estípulas, nectários foliares e inflorescências, porém a primeira diferencia-se por apresentar brácteas elípticas, cálice tubular, corola com lobos seríceos a vilosos, estigma cupular e fruto não apiculado; enquanto a segunda apresenta brácteas ovais, cálice cupuliforme, corola com lobos puberulentos, estigma globoso e fruto apiculado.

\section{Agradecimentos}

Os autores agradecem ao Programa de Capacitação Institucional (PCI) do Museu Paraense
Emílio Goeldi (MPEG) e ao Conselho Nacional de Desenvolvimento Científico e Tecnológico (CNPq) a concessão da bolsa e apoio logístico para a realização deste trabalho; à Rede CTPetro Amazônia e à Petrobras o auxílio nas viagens de coleta e aos assessores ad hoc as sugestões.

\section{Referências Bibliográficas}

Barneby, R.C.; Grimes, J.W.; Berry, P.E.; Brunner, D.; Forero, E.; Cárdenas, L.; Martino, G.; Hopkins, H.C.F.; Occhioni, E.M.L. 2001. Mimosaceae. In: Berry, P.E.; Yatskievych, K. \& Holst, B.K. Flora of the Venezuelan Guayana: Liliaceae-Myrsinaceae. Vol. 6. Missouri Botanical Garden, St. Louis. Pp. 580-686.

Bentham, G. 1876. Mimosaceae. In: Martius, C.F.P Von; Endlicher, S. \& Urban, I. Flora brasiliensis. Monachii, Lipsiae. Vol. 15. Pp. 258-527.

Bilia, D.A.C.; Barbedo, C.J.; Cícero, S.M. \& Marcos-Filho, J. 2003. Ingá: uma espécie importante para recomposição vegetal em florestas ripárias, com sementes interessantes para a ciência. Abrates 13: 26-30. 
Caramori, S.S.; Souza, A.A. \& Fernandes, K.F. 2008. Caracterização bioquímica de frutos de Inga alba (Sw.) Willd. e Inga cylindrica Mart. (Fabaceae). Revista Saúde e Ambiente 9: 16-23.

Ducke, A. 1949. As Leguminosas da Amazônia Brasileira. Boletim Técnico do Instituto Agronômico do Norte 18: $15-71$.

Fidalgo, O. \& Bononi, V.L.R. 1984. Técnicas de coleta, preservação e herborização do material botânico. Instituto de Botânica, São Paulo. 62p.

Garcia, F.C.P. 1998. Relações sistemáticas e fitogeográficas de Inga Mill. (Leguminosae-Mimosoideae) nas florestas da costa sul e sudeste do Brasil. Tese de Doutorado. Universidade Estadual Paulista, Rio Claro. 248p.

León, J. 1966. Central American and West Indian species of Inga (Leguminosae). Annals of the Missouri Botanical Garden 53: 265-359.

Lewis, G.P.; Schrire, B.; Mackinder, B. \& Lock, M. 2005. Legumes of the world. Royal Botanic Gardens, Kew. 577p.

Lima, S.O.F.; Martins, M.B.; Prudente, A.L.C.; Montag, L.F.A.; Monnerat, M.C.; Cabral, P.R. \& Rosário, D.A.P. 2008. Biodiversidade na província petrolífera de Urucu. Petrobrás, Rio de Janeiro. 194p.
Lorenzi, H. 2002. Árvores brasileiras: manual de identificação e cultivo de plantas arbóreas nativas do Brasil. Plantarum, São Paulo. 368p.

Mata, M.F. \& Felix, L.P. 2007. Flora da Paraíba, Brasil: Inga Mill. (Leguminosae - Mimosoideae). Revista Brasileira de Biociências 5: 135-137.

Pennington, T.D. 1997. The genus Inga botany. Royal Botanic Gardens, Kew. 844p.

Pritchard, H.W.; Haye, A.J.; Wright, W.J. \& Steadman, K.J. 1995. A comparative study of seed viability in Inga species: desiccation tolerance in relation to the physical characteristics and chemical composition of the embryo. Seed Science and Technology 23: 77-89.

Richardson, J.E.; Pennington, R.T.; Pennington, T.D. \& Hollingsworth, P.M. 2001. Rapid diversification of a species-rich genus of neotropical rain florest trees. Science 293: 2242-2245.

Sousa, M.S. 2009. Adiciones al género Inga (Ingeae, Mimosoideae, Leguminosae) para la flora mesoamericana. Acta Botanica Mexicana 89: 25-41.

Sousa, M.S. 1993. El género Inga (Leguminosae Mimosoideae) del sur de México y Centroamerica, estudio prévio para la Flora Mesoamericana. Annals of the Missouri Botanical Garden 80: 223-269. 